The Lahore Journal of Economics

$11: 2$ (Winter 2006) pp. 79-105

\title{
Regulatory Response to Market Volatility and Manipulation: A Case Study of Mumbai and Karachi Stock Exchanges
}

\author{
Jamshed Y. Uppal" and Inayat U. Mangla**
}

\begin{abstract}
This study examines the regulatory intervention in India and Pakistan in response to episodes of excessive market volatility and manipulation and its effectiveness in achieving declared objectives. Our empirical analysis indicates that while the Indian regulatory agencies seem to have achieved their objectives in curtailing manipulative and speculative behavior, there appears to be little impact on such behavior in the case of the Karachi Stock Exchange. Significant differences in the regulatory effectiveness and industry structure may explain the difference in the market behavior outcomes following regulatory interventions. A stronger competitive environment in India, because of the existence of multiple organized exchanges, seems to facilitate effective enforcement of public policy.
\end{abstract}

Key Words: Stock market volatility, manipulation, speculation, scams, corporate governance, regulatory dialectics.

Jel Classification: $G 15, G 18, G 28, K 22, O 16$

\section{Introduction}

The last two decades have seen unprecedented growth and volatility in the stock markets of developing countries. As emerging markets continue to grow and assume a more prominent role in the economy, the regulatory framework evolves along side, although with delays and sub-optimal solutions, which are characteristic of political processes. Regulatory development takes place, in many cases, as a response to financial crisis, scandals and scams in an effort to restore the investors' confidence in the markets and institutions. Financial service firms on the other hand indulge

\footnotetext{
* Corresponding Author: Associate Professor of Finance, Department of Business and Economics, Catholic University of America, Washington, D.C. 20064; Email: uppal@cua.edu.

Professor of Finance, Haworth College of Business, Western Michigan University, Kalamazoo, MI-49008;Email : inayat.mangla@wmich.edu.
} 
in avoidance behavior to circumvent regulation. The interplay of market evolution and regulatory response seems to be similar to the one described by Edward Kane in relation to the regulation of financial institutions (Kane, 1983 and 1988). Kane describes it in Hegelian fashion as "a delayed reaction to interacting dialectical processes." The conflicting elements play out as a Hegelian thesis and antithesis, to evolve into a new policy synthesis. However, the new synthesized policy mix generates its own contradictions in the ongoing dialectical process. We propose that in the case of emerging markets, a similar dialectic develops due to an unsustainable conflict between free market forces and the policy stance of regulators.

Public interest theory of regulation justifies intervention in cases of market failure due to monopoly or market power, asymmetric or imperfect information, and the existence of externalities or of public goods. Since informational imperfections are inherent in financial markets, a basic task of a financial regulator is, therefore, to reveal information and prevent the misuse of asymmetric or insider information. Regulators of financial markets should ensure efficient intermediation by financial markets of savings, price discovery, allocation of investment, and the pricing and hedging of risk. Regulatory agencies can add value by reducing problems of information asymmetry and moral hazard, by enhancing transparency and disclosure and mitigating conflicts of interest. Another feature of financial markets is the presence of network effects, where value to any one individual increases with the increase in the number of participants. The resulting herding behavior can lead to excessive volatility and sharp swings in the stock prices (Wilhelm, 2001).

The regulators in the emerging markets should be concerned about excessive volatility since, among other factors, it reflects possible market manipulation and speculative trading. A lack of trust in the fairness of markets due to the potential for manipulation and irrational trading, highlighted by recurring scandals, scams, and speculative bubbles, exacerbates market volatility. Such manipulative and speculative behavior imposes implicit costs on market participants and increases the cost of intermediation. The inefficiencies in market intermediation increase the cost of capital, which can be a drag on the economic development. Kane (1988) sees financial instability as a cost of inefficient financial regulation. Mian and Atif (2005) document the direct cost of poor governance of market intermediaries. A major task for the regulator thus becomes reducing volatility.

In this study we describe the regulatory dialectics in two emerging markets in South Asia, namely India and Pakistan, which lend themselves for 
comparative analysis of regulation of markets due to commonalities in institutional structures and traditional financial instruments and practices. The two markets share a common genesis, a common civil code, and a similar cultural and regulatory environment. In recent times the two markets have had their own cycles of boom and bust, periods of superlative growth, as well as of sharp decline and volatility.

In section II we draw comparisons between the cycle of dialectics in the two countries, regulatory response to market manipulation and volatility, and its effectiveness in achieving declared objectives. We study episodes of speculative market behavior and regulatory response in India and Pakistan; two episodes in the former and one in the later. In these periods, allegations of massive speculation, manipulation and scandals led to political pressures on the regulators to phase out a traditional institution common to the two countries, that is, of "badla" or Carry-Over-Trade (COT) financing, which is explained in the following section. In section III we provide a brief description of the speculative episodes and the regulatory response in the two countries. Section IV explains the empirical methodology used to examine the change in market behavior following regulatory intervention. Section V presents results of the study. We note that while the Indian regulatory response seems to have achieved its objectives in curtailing manipulative and speculative behavior, there seems to be no impact on such behavior in the case of the Karachi Sock Exchange (KSE). The final section presents summary and conclusions.

\section{Institutional Background:}

\section{Bombay Stock Exchange (BSE)}

The Bombay Stock Exchange (BSE, now known as The Stock Exchange, Mumbai) is the oldest stock exchange in Asia, established in 1875. Over 4,700 stocks, with a total market capitalization of about US $\$ 553$ billion, are traded on the exchange. The BSE is among the 5 biggest stock exchanges in the world in terms of transactions volume. Along with the National Stock Exchange (NSE), an emerging competitor established in 1994, the two exchanges represent more than a four-fifth share in aggregate turnover of the 23 stock exchanges in the country. The BSE was organized as an Association of Persons (AOP) until 2005, when the Exchange was demutualized and incorporated as an corporate entity. With the conversion from a mutual form to the corporate form, the trading rights and ownership rights have been delinked to address concerns regarding perceived and real conflicts of interest. 
Following the economic reforms of July 1991, Indian stock markets have increasingly integrated with developed markets. Their exposure to fluctuations in global stock markets has increased as foreign institutional investors have become major players in the domestic markets since 1993. Over the years, Indian stock markets have strived to transform themselves to meet the demands of modern finance, for example, by developing a fullfledged derivatives market for futures and options. In the last decade, Indian stock markets, particularly the BSE, have witnessed many booms and busts and weathered several crises. The Sensex (BSE30), considered to be the barometer of the Indian economy, has shown relatively higher volatility during the post-reform period. The BSE has also seen a recurrence of financial irregularities; in the last decade two major and a few minor scams have affected the market badly.

A major institutional development was the setting up of the National Stock Exchange (NSE). The Bombay stock exchange was perceived to be backwards, and as an obstacle in the modernization of the capital markets. The National Stock Exchange of India was promoted by leading financial institutions at the behest of the Government of India, and was incorporated in November 1992. Within one year of the onset of equity trading at the NSE, it became India's most liquid stock market. The launch of derivatives in 2000 by the NSE further choked the Bombay Stock Exchange, which has lost market share to the NSE every year since then. In equity trading volume the BSE share slipped from $45 \%$ in 2000 to under $32 \%$ at present.

The NSE succeeded by harnessing new technology, building an ownership structure that kept it free of public sector bureaucratic control, adopting modern management practices, and basing its business model on user charges. Shah and Thomas (2001) summarize that, "NSE seems to have generated a dynamic process of change in the securities industry. It directly spawned new institutions (the clearing corporation and depository) and played a vital role in injecting new ideas into the securities markets (such as derivatives trading). Through competitive pressure, and by being a role model, it indirectly helped accelerate the process of change in other exchanges in the country. Thus the NSE's overall importance in the reforms process on the equity market has been quite considerable."

\section{Karachi Stock Exchange (KSE)}

The Karachi Stock Exchange (KSE), established in 1947, is the oldest and the most active of the three stock exchanges in Pakistan, and currently lists 662 companies with a total market capitalization of about \$52 
billion. The KSE100 represents major blue chips companies and is fairly representative of the market. Besides the KSE there are two regional stock exchanges in Lahore and Islamabad. The other two exchanges are however relatively inactive. For example, during July 2005-March 2006 the average daily turnover at the KSE was 462.4 million share, while at the LSE and ISE it was 65.4 and 1.7 million shares, representing $12 \%$ and $3 \%$ of the total market activity respectively.

Similar to other emerging markets, the KSE has a limited role in raising new capital; e.g., there were only five new listings in the market in 2005. Despite the small size of the market, it experiences a high turnover and high price volatility. From the plot of the KSE100 index over the five year period 2001-2005 (See Figure 1), one can see that the market experienced significant fluctuations over shorter time intervals. Finally, a skewed size distribution of stocks traded is observed for the KSE i.e., skewed in terms of size, trading patterns, volume of brokers' trading and weighted value of stocks in the index. This is particularly true for the top 20 stocks accounting for $85 \%$ of the overall turnover.

Exhibit A shows the salient features of the BSE and KSE for comparison. The KSE is a much smaller market compared to the BSE, both in terms of listed companies as well as market capitalization. The KSE represents only $0.7 \%$ of the total capitalization of emerging markets, compared to the BSE's $7.9 \%$ share. It is interesting to note the sharp contrast between Pakistan's capitalization ratio (which is low) and relatively high turnover ratio. This characteristic probably reflects noise trading and speculative elements in the market. The spectacular rise in the S\&P/IFC Global Index of $410 \%$ over the $2001-05$ period is remarkable, though the BSE's $260 \%$ appreciation also stands in sharp contrast with the performance elsewhere in the world. The appreciation in the KSE100 index and BSE30 index was $534 \%$ and $137 \%$ respectively for the same period. The Pakistani stock market appreciation was four times higher than the Indian market, despite a higher rate of growth in the Indian GDP for the same period. Exhibit A also shows that the PE ratio and Price to Book value of Pakistani companies included in the S\&P/IFC Global Index is nearly $2 / 3$, and the dividend yield nearly half of that of the Indian companies. These statistics suggest that the cost of capital for the Indian companies would be much lower than for the Pakistani companies. Another important difference is the higher degree of correlation of the BSE (0.69) with the S\&P Composite Index, compared with correlation coefficient of 0.32 in case of the KSE, which reflects a higher degree of integration of the BSE with the international capital markets. 
Exhibit A: Comparative Market Statistics

\begin{tabular}{|c|c|c|c|c|}
\hline Market Statistic & \multicolumn{2}{|c|}{$\begin{array}{l}\text { Mumbai Stock } \\
\text { Exchange }\end{array}$} & \multicolumn{2}{|c|}{$\begin{array}{l}\text { Karachi Stock } \\
\text { Exchange }\end{array}$} \\
\hline Year & 2001 & 2005 & 2001 & 2005 \\
\hline No of listed Companies & 5,795 & 4,763 & 747 & 661 \\
\hline Market Capitalization (mil. US \$) & 110,396 & 553,074 & 4,944 & 45,937 \\
\hline Trading Value (mil. US \$) & 249,298 & 443,175 & 12,455 & 140,996 \\
\hline Turnover ratio (\%) & $191.4 \%$ & $93.6 \%$ & $226.8 \%$ & $375.7 \%$ \\
\hline P/E Ratio* & 12.8 & 19.4 & 7.5 & 13.1 \\
\hline Price to Book Value* & 1.9 & 5.2 & 0.9 & 3.5 \\
\hline Dividend yield (\%)* & $2.4 \%$ & $1.3 \%$ & $12.5 \%$ & $2.5 \%$ \\
\hline $\begin{array}{l}\text { \% Change in index (2005 over } \\
2001)^{*}\end{array}$ & & $260 \%$ & & $410 \%$ \\
\hline $\begin{array}{l}\text { Share of emerging market } \\
\text { capitalization }\end{array}$ & & $7.9 \%$ & & $0.7 \%$ \\
\hline S\&P/IFCG Index correlation & & 0.69 & & 0.32 \\
\hline $\begin{array}{l}\text { Gross Domestic Product } \\
\text { (mil. US \$) }\end{array}$ & 478,524 & $691,163^{* * *}$ & 71,496 & $96,115^{* *}$ \\
\hline
\end{tabular}

Source: Global Stock Markets Factbook 2006, Standard and Poor's.

Note: * based on S\&P IFC Global Index; ** 2004 figures

Besides the differences between the two markets in size, activity and other characteristics noted above, there are two aspects of the markets which may have a direct bearing on the regulatory response and its effectiveness in dealing with market manipulation and volatility in the two countries. First, there is a difference in the industry structure and competition among the stock exchanges. As already noted above, the India National Stock Exchange has emerged as the leading stock exchange in the country, with $45 \%$ market share, thus eliminating the BSE's monopolistic position that it enjoyed since its inception. The NSE along with 22 other active regional exchanges creates a more competitive environment than is the case in Pakistan. The KSE is still the dominant player in this case with a $85 \%$ share of the trading activity.

Secondly, there seems to be a significant difference between regulatory enforcement and effectiveness of public policy. Nageswaran and Krithivasan (2006), for example, claim that only Singapore, Hong Kong and 
India are effective in enforcement among Asian countries. According to data compiled by Goyal (2004), the Securities and Exchange Board of India (SEBI) had taken up 657 cases for investigation in the period 1992-2003, and had completed 424 cases. 250 prosecutions were launched against collective investment schemes over 2001-03. During the same year there were 257 actions taken against brokers and others out of which there were 42 suspensions. SEBI's record in redressing grievances also appears to be effective; the redress rate is about $95 \%$. In contrast, according to a survey conducted by La Porta et a1. (2006) Pakistan scores rather low on the indices of (i) orders to issuers, distributors and accountants (ii) criminal sanctions and (iii) public enforcement which capture the extent to which a public regulator exercises investigative power and its ability to impose penalties. Pakistan's score on these three indices is $0.17,0.08$ and 0.58 , compared to India's $0.67,0.83$ and 0.67 respectively. Mian and Atif (2005) remark with respect to Pakistan that, "Thus, it is not surprising that to date there has hardly been any case in which a broker was prosecuted for improper activity."

\section{The Badla or Traditional Carry Forward System}

An old and traditional informal institution common to both India and Pakistan is that of "badla", meaning something in return. It is a local term for a forward trading facility, and essentially is a repo transaction carried out in a separate after-hours market where the borrower who takes the badla from a badla broker, carries forward his security exposure from the current settlement period to the next one, by sale of his position in the present period and its repurchase in the subsequent settlement period at a predetermined price differential. In the event of a purchase, the investor may want to carry forward the transaction to the next settlement cycle and for doing so, he has to compensate the seller who sold it with an intention of getting cash.

\section{Market Crisis and Regulatory Response}

\section{The Indian Experience}

In June 1991, the new Indian government accelerated the process of economic liberalization, privatization and opening up of the economy, setting off expectations of unprecedented growth and prosperity for the economy. The stock market started booming - the BSE Sensitive index rose from around 1000 in February 1991 to a peak of 4500 in March 1992. There was an enormous increase in the demand for margin finance by investors. On the other hand, there were heavy margins imposed by the 
BSE, which led the market participants to find innovative solutions, sometimes not legal, to meet their financing requirements.

The new free market environment put immense pressure on the public sector, in particular the nationalized banks, to improve financial performance and capital adequacy. Banks, holding large cash balances not subject to reserve requirements under the Portfolio Management Scheme and cash raised by the public sector units through foreign exchange borrowing, became eager to explore new venues of higher returns. The market did not take long to find innovative ways of avoiding regulation and diverting funds from the banking system (from the inter-bank market for government securities) to the stock market. It was done mainly through the ready forward deal mechanism, a variant of repo or repurchase agreement, and the badla system often using fraudulent and non-existing securities. The resulting "securities scam," personified by Hashad Metha, led to a diversion of funds to the tune of over $\$ 1.2$ billion from the banking system to the stock market during the period April 1991 to May 1992. For a detailed reconstruction of the scam and regulatory response see Barua and Varma (1993).

With the discovery of the scam, stock prices dropped by over $40 \%$ in less than two months, wiping out market value by $\$ 35$ billion. The government responded by promulgating an ordinance with several harsh provisions, including confiscation of the properties of the accused in the scam. It set up a special court to try those accused in the scam. It also voided all transactions in "tainted shares" that had been routed through involved brokers and their firms, which also caused market disruption. Another unintended consequence was to slow down the reform process which busted the speculative boom of the early 1990's.

The badla system was blamed for causing "excessive speculation" in the market and for the irregularities in the stock exchanges in the form of non-enforcement of margins, non-reporting of transactions and illegal trading outside the stock exchange. Consequently, in March 1994 the Securities and Exchange Board of India (SEBI) effectively banned the facility, but, yielding to the demands from the brokerage community, introduced a modified badla system subject to certain safeguards effective January 1996. In 1997 further safeguards were put in place, such as segregation of carry forward transactions at the time of execution of trade, daily margins of $10 \%$, one-half of which would be collected upfront, and overall carry forward limits per broker.

Barua and Varma (1993) argue that the origin of the scam lie in overregulation and artificial barriers between the money market and the 
capital market. In terms of Kane's regulatory dialectics, major shifts in the technological and market constraints created contradictions with the antiquated regulatory framework. The regulatees' adaptive response of circumvention led to a sequence of avoidance-reregulation and avoidance.

In the late 1990's the dotcom boom in information, communications, and entertainment stocks all over the world contributed to the bull run on the BSE, which almost doubled in a short period from January 1999 to February 2000. The speculative spell led to overextended positions, and afforded many opportunities for fraud and manipulation, personified by the Bombay Bull, Ketan Parekh, considered to be the main villain. He had managed to manipulate ill-liquid stocks, known as the ' $\mathrm{K}-10$ ' stocks, by borrowing from various companies and banks using the shares as collateral. It worked well in the bull market, but busted when the markets started crashing in March 2000, led by a fall in the NASDAQ. In the next two months, while the NASDAQ declined by $35.9 \%$, the Sensex lost $23 \%$ and the K-10 stocks crashed by $67 \%$ (see ICFAI, 2002).

Following the crash in the stock markets, SEBI launched immediate investigations into the volatility of stock markets. SEBI also decided to inspect the books of several brokers who were suspected of triggering the crash. The Reserve Bank of India (RBI) ordered investigation into the capital market exposure of some banks, following media reports that some banks may have exceeded prudential norms of capital exposure, thereby contributing to the stock market volatility. The Bombay Stock Exchange (BSE) President was forced to resign following allegations that he had used some privileged information, which contributed to the crash. In the aftermath, at least eight people were reported to have committed suicide while hundreds of investors were driven to the brink of bankruptcy. The scam brought into question banks' funding of capital market operations and lending funds against collateral security. It also shattered investors' confidence in the functioning of the stock markets.

It appears that the dot-com bull market strained the regulatory framework through a manifold increase in the trading volumes, market value, and need for liquidity and financing. A conflict between economic forces and the regulatory processes developed as the regulatory adaptations lagged behind market developments. Ineffective regulations and surveillance of banking system and stock market financing (in particular informal financing through badla) permitted illegal and highly speculative positions. The ensuing market crash prompted SEBI to launch a cycle of regulation to control the damage including increasing margin requirements, imposing restrictions on short sales, and requiring stock deliveries following sale. It 
suspended all of the broker member directors of BSE's board and banned trading by exchange officers. The badla system was banned, effective from July 2001, and a rolling settlement system was introduced.

\section{The Pakistan Experience}

The KSE experienced a steady bull run as reflected in both the KSE 100 index and trading volumes, starting just after the last stock market crisis in May 2002, which accelerated towards the end of 2004. The KSE 100 saw an unprecedented rise of $65 \%$, from 6,218 on December 31, 2004 to 10,303 on March 15,2005 , along with an increase in the value traded from around $\$ 300-400$ million to $\$ 1-2$ billion per day. The market turned negative in the second half of March, 2005 and the index dropped as low as 6,939 on April 12, 2005, a decline of $32.7 \%$ from its peak. The sharp rise in the index could not be explained by any change in the fundamentals. The following precipitous fall is also somewhat of a puzzle. Such a meteoric rise in index and a subsequent crash is indicative of a classical speculative bubble in the equity market.

Badla has been blamed as one of the reasons for the March 2005 crisis. Pakistan's influential financial newspaper The Business Recorder stated two problems with "badla" financing: first, badla financing is only open to a small number of market players, which also includes financial institutions, as opposed to share trading. Second, badla financing is provided by short-term investors and the hot money can disappear overnight. During 2004-05 KSE investors were willing to borrow at exorbitant badla rates (which were capped at $18 \%$ in the KSE, but rose in the uncapped Lahore Stock Exchange to over 100\%) because the accelerated rise in stock prices made even expensive borrowing feasible. The COT (badla) financing ranged from $33 \%$ to $45 \%$ of investment at KSE throughout 2004. The higher demand for badla investment pushed the average badla rates from $9.4 \%$ in 2003 , to $11.4 \%$ in 2004 , ranging from 12 to $19 \%$, even though market interest rates remained stable at a relatively low level through most of 2004 .

The growing availability of badla financing brokers and institutions added to the buying frenzy, though some of the major badla providers were simultaneously selling in the futures market. In other words, "there was a strong nexus between lenders and brokers/investors who could influence market sentiment to their own advantage" (Task Force Report, 2005). The chairman of SECP stated on July 16, 2005 that "badla" was the root cause of almost all previous crises at the bourses, and was to be rooted out, and that the badla and margin financing could not co-exist. 
After the March 2005 crisis, a task force was set up by the Chairman of SECP to identify the causes for the situation arising at the country's three stock exchanges in March 2005 and to propose measures for strengthening and consolidating the regulatory regime, particularly with a view to enabling emergency intervention, preventing systematic risk and promoting market stability. The task force completed its report in July 2005 identifying a few areas that contributed to the instability in the stock prices. The Task Force recommended that there was a need for structural reforms and steps were needed to protect public interest by ensuring that the financial might that has been accumulated by the stock brokerage and badla financing institutions should be effectively checked and brought to a reasonable size to ensure that they are unable to manipulate the market and adhere to international practices.

Besides badla financing, other factors which contributed to this "bull run" included, increased liquidity due to higher foreign remittances, a regime of low interest rates, IPO's of public sector enterprises marked for divestment and floatation of more mutual funds. During this period, especially since the middle of October 2004, there was an unusual build-up in the media about the prospects of a rise in the KSE index. Statements from government officials linked the rise in the KSE index to good economic management, and indicated that the market was destined to rise further. The announcement of the impending accelerated program for the privatization of prominent and profitable public sector corporations fuelled the bullish sentiment. The conduct of corporate officials contributed to the market speculation; for example, rumors of new oil and gas discoveries which would raise stock value manifold went un-refuted or clarified by the management. There were allegations of "wash trades" and "pump and dump" plays by brokers.

The main thrust of the Pakistani regulators was to replace badla with formal financing arrangements. The State Bank of Pakistan (SBP) in collaboration with the Securities and Exchange Commission of Pakistan (SECP), came out with rules governing margin financing issued to stock brokers by banks. The SBP rules specified the conditions of extending such loans to stock market brokers with proper risk management and internal controls. It has also specified the minimum margin requirement of $30 \%$ and reminded banks of the per party limit, in case of such lending to brokers. The SECP intended to completely eliminate the carryover market (the badla market) by the end of December 2004. Initially, the plan was to replace it in 2003 , but slow progress by the regulators has resulted in a delay.

Regarding replacement of badla financing, the regulatory bodies were seen as vacillating, as was described in an op-ed "Badla is back" in the 
newspaper, the News. "But firmness doesn't appear to be the strong point of the Securities and Exchange Commission of Pakistan. ... What went wrong? Or, rather, how heavy was the pressure from vested interests? Were the members of the Karachi Stock Exchange so powerful that they managed to force the regulator to work in their interest? The SECP has not only proved to be a weak regulator but also exposed itself to the criticism that it acts first and thinks later," (The News, July 15, 2005).

There were other factors which reduced the effectiveness of the regulators' actions. First, the composition of the Task Force was not without conflicts of interest as its members also were on the Policy Board investigating matters which should have been the subject matter of the Board itself when formulating capital markets policies. Second, the common view is that the March debacle was due to excessive institutional selling and the withdrawal of badla financing simultaneously from the market. In the past, SECP had been criticized for allowing the brokerage houses to own commercial and investment banks which provided them additional resources to enter into badla financing and use it to manipulate the market. Third, the Task Force, a creation of SECP, could not look into the question of inadequate surveillance and weak implementation by SECP.

The Task Force also did not look into the role of KSE management in possibly precipitating the withdrawal of the badla facility, by calling upon the various brokers and institutions to reconfirm that they would be able to honor their obligations in the future contracts, and sending alarming signals to market players. As there were four SECP nominated directors on the KSE board, there was a possibility of conflict of interest. However, while the KSE does receive some oversight from the SECP, it is predominantly brokermanaged, i.e., a majority of the exchange's board of directors including the chairman are brokers. The Task Force also did not investigate the allegation of market manipulation by certain mutual funds through withdrawing the badla financing and to take advantage of the pursuing crash.

\section{Empirical Analysis and Methodology}

In order to empirically analyze the impact of the regulatory intervention, primarily abolishing of badla system, following market scams and episodes of speculative behavior, we study the return volatility in the two stock exchanges before and after the events. It is strongly argued in the finance literature (e.g., De Long, Shleifer, et al. 1990a, 1990b) that noise traders cause excessive trading and volatility. Speculative trading in derivative securities has also been blamed for causing excessive volatility (Jegadeesh and Subrahmanyam, 1993). Some economists have even argued 
for imposing tax on short-term trades to contain volatility (e.g., Stiglitz 1989).

Among the related research, in the context of India, Bhattacharya et al. (2003) examine the stability of the day-of-the-week effect in returns and volatility during 1991-2000 and do not find the estimated coefficient of the dummy variable for badla financing to be significant. Goswami and Angshuman (2000) also report that badla trading had no impact on the dayof the-week pattern of returns. Eleswarapu and Krishnamurti (2005) study whether badla financing facility had led to speculative volatility on the Bombay Stock Exchange prior to March 1994. They do not "find any evidence that supports the allegations made by regulators that badla trading destabilizes the stock prices and causes excessive volatility." The impact of abolishing of badla system in Pakistan has not been studied so far to our knowledge. However, Ahmed, Rosser and Uppal (1996) document the existence of bubbles over the period 1987-1994. Mangla and Uppal (1996) report market inefficiencies. The existence of price manipulative behavior on the KSE is rigorously documented by Khawja and Mian (2005).

We conduct empirical analysis of the impact of regulatory intervention in the two markets in order to subdue speculative behavior with reference to stock price volatility. First, we examine the variance of stock returns and conduct an F-test for variance equality. Second, we modify the variance tests to exclude possible influence of the international stock markets and conditional auto-regressive heteroskedasticity on the variance process. Variance of the residuals from the GARCH-M model in the beforeand after- sub-periods are tested for equality by employing the usual F-test. Third, we include a dummy variable in the GARCH variance equation to capture the impact of the regulatory response on the market volatility. Finally, we examine autocorrelation in the market returns in the two subperiods. The GARCH methodology is further explain below.

Autoregressive conditional heteroskedasticity (ARCH) was proposed by Engle (1982) to explain the tendency of large residuals to cluster together. A general form of an ARCH/GARCH model is:

$$
\begin{aligned}
& \mathrm{y}_{\mathrm{t}}=\mathbf{X}_{\mathrm{t}} \beta+u_{\mathrm{t}} \text { and the variance of } u_{\mathrm{t}}, \boldsymbol{h}_{t} \text { follows the process: } \\
& \boldsymbol{h}_{t}=b\left(u_{t-1}, u_{t-2}, \ldots u_{t-q}, h_{t-1}, h_{t-2} \ldots, h_{t-p}, X_{t-1}, X_{t-2}, \ldots, X_{t-k} \alpha\right)
\end{aligned}
$$

where $\alpha$ is a set of unknown parameters. In the Bollerslav (1986) model, the variance term depends upon the lagged variances, as well as the lagged 
squared residuals, to model persistence in volatility. The variance model for the standard GARCH (p, q) model is:

$$
h_{t}=c_{0}+a_{1} u_{t-1}^{2}+a_{2} u_{t-2}^{2}+\ldots+a_{q} u_{t-q}^{2}+b_{1} h_{t-1}+a_{2} h_{t-2}+\ldots+b_{p} h_{t-p}
$$

GARCH-M models (Engle, Lilien, Robins (1987)) generalize the GARCH model by allowing a function of the variance (typically the variance itself) to enter the regression function. We employ a $\operatorname{GARCH}-\mathrm{M}(1,1)$ model to account for the persistence in volatility in the returns series as follows:

$$
\begin{aligned}
& \mathrm{R}_{\mathrm{t}}=\gamma_{0}+\gamma_{1} \mathrm{RI}_{\mathrm{t}}+\gamma_{2} \boldsymbol{h}_{t}+\boldsymbol{u}_{\mathrm{t}} \quad \text { where } \boldsymbol{u}_{\mathrm{t}} \sim \mathrm{N}\left(0, \mathrm{~h}_{\mathrm{t}}\right) \\
& \boldsymbol{h}_{t}=\operatorname{var}\left(\boldsymbol{u}_{\mathrm{t}}\right)=\boldsymbol{c}_{0}+\boldsymbol{a}_{1} u_{t-1}^{2}+\boldsymbol{b}_{1} \boldsymbol{b}_{t-1}
\end{aligned}
$$

In our model the set of explanatory variables $\left(\mathbf{X}_{t}\right)$ consists of a vector of 'returns' on the MSCI World Index measured as $R I_{t}=\ln \left(I_{t}\right)-\ln \left(I_{t}\right.$ $\left.{ }_{1}\right)$, as well as the conditional variance $\left(b_{t}\right)$. The MSCI world index is included in the mean equation to capture the transmission of volatility from the international markets to the local market, which has been well documented in empirical research, and to allow us to focus on volatility arising from domestic factors. The conditional variance $b_{t}$ is included in the mean equation to include the risk-return trade-off predicted in the finance literature, allowing for a more general specification of the return generating process. Though the relationship between portfolio returns and conditional variance (as a proxy for risk) is not a central issue in this paper, we note here that there are theoretical arguments predicting both a positive as well as a negative relationship between these two variables. The empirical evidence has also been mixed (see Shin (2005) for a recent survey).

Variance of the residuals from the GARCH-M model in the beforeand after- regulatory change are then tested for equality employing the usual F-test. The impact on return volatility following regulatory response is further examined by including a dummy variable $D_{t}$ in the variance equations (2) which takes a value of one for period after the change in the regulations and zero otherwise. The variance equation with the regulatory dummy is now as follows:

$$
h_{t}=c_{0}+a_{1} u_{t-1}^{2}+b_{1} h_{t-1}+d D_{t}
$$

The coefficient on the dummy variable should capture the impact of regulatory intervention on the volatility of the market returns. 


\section{Data and Sample Period}

Data for this study was taken from the Datastream International, Ltd. Database for the Karachi Stock Exchange 100 Index (KSE100) and for Bombay Stock Exchange index of 30 major companies (BSE30 SENSITIVE). Daily closing values of the indices were used for the period from 1/1/1993 to $12 / 29 / 1995$, and from $1 / 1 / 2000$ to $3 / 31 / 2003$ for the BSE to cover the two periods during the period of change. The corresponding event window is from $1 / 1 / 2004$ to $8 / 30 / 2006$ for the KSE. We study the market behavior by dividing it into sub-periods, before and after the structural change was implemented, as shown below (Exhibit B):

Exhibit B: Study Period

\begin{tabular}{lllc}
\hline Market & Event Date & \multicolumn{1}{c}{ Study Sub-Periods } & $\begin{array}{c}\text { No of } \\
\text { Observations }\end{array}$ \\
\hline BSE & March, 1994 & Sub-Period I: $1 / 1 / 1993$ to $2 / 28 / 1994$ & 302 \\
& & Sub-Period II: 6/1/1994 to 12/29/1995 & 413 \\
& \multirow{2}{*}{ July, 2001 } & Sub-Period I: 1/1/2000 to 6/29/2001 & 390 \\
& & Sub-Period II: 10/1/2001 to 3/31/2003 & 391 \\
KSE & \multirow{2}{*}{ March, 2005 } & Sub-Period I: 1/1/2004 to 2/28/2005 & 303 \\
& & Sub-Period II: 8/1/2005 to 8/30/2006 & 283 \\
\hline
\end{tabular}

For the BSE, we leave out a three month intervals between the subperiods to allow the market to adjust to the new regulatory environment. For the KSE, we exclude five months since the issue remained under consideration for longer period and the change was not implemented immediately. All price data was converted to "returns" by taking the natural $\log$ differences of the index level $P_{t}$ thus: $R_{t}=\ln \left(P_{t}\right)-\ln \left(P_{t-1}\right)$.

\section{Results}

Figure 1 presents graphs of the market indices and return volatility for BSE and KSE for the periods under study. It is important to note that the Bombay stock exchange was quite bullish before the event date, March 1994, but had a mixed experience afterwards. During the 2000-03 period, the BSE index shows a general bearish trend. The graph for the KSE, however, shows that the market was strongly bullish before March 2005, but resumed its bullish course, after a brief 'crash' over the 3-4 month period. It is also observed that that the return volatility was lower for the 
BSE in the post intervention sub-periods, while the volatility was higher in second sub-period for the KSE.

Summary statistical results for the first four moments for the return series are shown in Table-1. It is noteworthy that the return distributions in both countries exhibit significant departure from the normal distribution, Skewness and Kurtosis are very significant, and the Jarque-Bera statistic for both markets and for all periods strongly rejects normality hypothesis. Results for tests for difference in mean and variance of two sub-period samples are presented in Tables-2 and 3 respectively. For the 1994 instance of abolishing badla in India, the mean daily return for the BSE in the first sub-period is $0.1636 \%$, while it is $-0.0503 \%$ in the second sub-period. The t-test for mean difference is significant at $5 \%$ leve1; one-tail probability $(\mathrm{T} \leq \mathrm{t})$ is $3.5 \%$. On the other hand, for the second event of banning badla system in 2001, the mean difference is not significant at conventional levels; the achieved significance leve1 is $16.2 \%$. In Table-2, the t-test for mean difference in the daily return on the KSE in the two sub-periods is not significant; the one-tail probability $(\mathrm{T} \leq \mathrm{t})$ is 23.6\%. Though the mean difference is not significant, it is interesting to note that the sample mean daily returns in second sub-period, though lower than in the first sub-period, remains high relative to historic experience and to the other emerging markets. It seems that the KSE bullish sentiment continued to rule, contrary to the intentions of the regulators.

Table-3 (pane1 A) presents the test results for difference in the variance over the studied events in the two markets. For the BSE, the F-test for unequal variance strongly rejects the null hypothesis both for the 1994 and 2001 episodes. For the 1994-95 study period the variance of daily returns in the second sub-period was significantly lower than in the first; $0.0126 \%$ compared with $0.0327 \%$. Similarly, for the $2000-03$ study period, the variance in the later sub-period $(0.0128 \%)$ is significantly lower than in the first sub-period $(0.0420 \%)$. The behavior of the KSE, however, appears to be quite the opposite. The sample variance is actually higher in the second period than in the first, $0.0280 \%$ vs. $0.0098 \%$, or approximately 2.8 times the first sub-period variance. The F-test for unequal variance rejects the null with a $\mathrm{p}$-value of practically zero.

In order to study the response of the two markets with respect to the regulatory changes with more robust controls, we account for the possibility of international stock markets and conditional auto-regressive heteroskedasticity influencing the variance process. It was accomplished by including the MSCI World index in a GARCH-M model and then 
conducting an equality of variance F-test on the residuals. The results of the test of variance equality are presented in pane1 B of Table-3. The results confirm the conclusion from the test on unadjusted variances reported in panel A, i.e., for the Indian experience the volatility subsided following regulatory measures, while it was exacerbated in the case of $\mathrm{KSE}$. The shift in the variance is in the opposite direction for the two markets and is statistically significant in all cases with p-values approaching zero.

Table-4 reports results from estimation of the GARCH-M model with a dummy variable representing the regulatory change. The dummy variable for the Indian market has a negative coefficient which is statistically significant at $5 \%$ significance level. It indicates that the variance of the return process dropped significantly after the regulatory intervention. On the other hand in the case of the Karachi Stock Exchange the dummy variable is not statistically significant, although it is of positive sign. Thus the more robust test for the shift in volatility tends to support the conclusions of the simple test of variance equality. It is worth noting here that all GARCH variables $\mathrm{C}, \mathrm{A}$ and $\mathrm{B}$, corresponding to the GARCH equation (2) are statistically significant. In addition, the coefficient for MSCI World Index is statistically significant for the Indian market, while not significant for the Pakistani market. It seems to point to the greater integration of the Indian stock market with the financial markets of the rest of the world. We also observe that the coefficient on the GARCH-variance $\left(b_{t}\right)$ is insignificant and of mixed sign, consistent with the weak and mixed results reported elsewhere (e.g., see Shin 2005).

We also examine the autocorrelation in the return series in the sub-periods following regulatory intervention, which is regarded as one indication of the speculative behavior. The estimated autocorrelations are reported in Table-5. The first order autocorrelation for the BSE in the 1993-1995 period seems to subside in the second sub-period, while it seems to increase in the second sub-period during 2000-03 episode. While the evidence from the autocorrelation function is mixed for the Indian case, in case of KSE the first-order autocorrelation is of a large magnitude (0.0988) and statistically significant in the period following regulatory intervention, compared to the pre-intervention period (-.0366). The increase in the autocorrelation function further suggests that the speculative behavior continued despite the changes brought about by the Pakistani regulators. 


\section{Summary and Conclusions}

In this paper we have analyzed episodes of marker manipulation and volatility and regulatory intervention in two emerging South Asian markets, India and Pakistan. These episodes conform well to Kane's theoretical framework of regulatory-dialectics depicting the interaction of financial and regulatory innovation. We observe a common pattern of avoidancereregulation-avoidance, triggered by changes in the market and technological environment. Markets adapt to such changes in the form of innovation, avoidance and circumvention of regulation. The resulting conflict calls for a re-regulation response, which, however, is followed by another round of avoidance.

We draw comparisons between regulatory responses in the two countries to the episodes of speculative spells, manipulation and scandals and its effectiveness in achieving declared objectives. Our empirical analysis indicates that while the Indian regulatory agencies seem to have achieved their objectives in curtailing manipulative and speculative behavior, there seems to be little impact on such behavior in the case of the KSE. The bullish sentiment and volatility on the KSE continued unabated despite the measures taken by the SECP to curtail speculative trading allegedly fanned by the badla system. On the other hand, the regulators of the BSE appear to have succeeded in their goals of cooling off the market in the 1994-1995 as well as in the $2000-03$ periods.

Though there are commonalities in terms of civil code, and cultural and business environments in the two countries, we note significant differences in the regulatory effectiveness and industry structure that may explain the difference in the market behavior outcomes following regulatory interventions. We note that the response of the Indian regulators in dealing with the market manipulations and speculative behavior appears to be much stronger and effective than was the case in Pakistan. The Indians regulatory response was three pronged: 1) discovering and punishing the guilty, 2) recovering the money, and 3) reforming the system. The Pakistani regulators on the other hand only pursued institutional restructuring mainly focusing on replacement of the badla system. No criminal or civil charges were filed, and no recovery was sought. This response may have been perceived by the market as weak, and may not have conveyed a strong signal to the market regarding government's resolve for effective enforcement. It is possible that extramarket manipulations by speculators, such as documented by Khawja and Mian (2005), may have frustrated the efforts of the KSE regulators. 
Another possibility is that the badla system may not have been a cause of the alleged speculative fever, as is reported by researchers for the BSE.

Another relevant factor is that in India, the National Stock Exchange is a viable competitor to the BSE. The competitive environment creates stronger pressures on the regulatees to self-regulate, reform, modernization and comply with the public policy. It strengthens the hands of the regulators in dealing with the recalcitrant and vested "clubby" organizational cultural which allegedly surrounds both stock exchanges. In the case of the $\mathrm{KSE}$, however, its near monopoly position may have been a factor in frustrating the goals of the regulators.

Kane (1988) hypothesizes that innovation discovery and execution lags are typically shorter for regulatees than for regulators; in other words, private sector players are nimbler than bureaucrats. He attributes this difference to "differences in relevant information costs, differences in the extent of managerial commitment to the goals of regulation, and differences in the extent to which principal-agent conflicts can be resolved in government and private enterprises." The difference in effectiveness of public regulation in the two countries observed here may similarly be attributable to these factors. Future reforms in Pakistan should focus on reducing conflict of interest and agency problem in both private and public sectors improving enforcement and surveillance, as well as creating a more competitive environment among the stock exchanges.

Table-1: Summary Statistics

\begin{tabular}{|c|c|c|c|c|c|c|c|c|c|}
\hline \multirow[b]{2}{*}{$\begin{array}{c}\text { Index Return } \\
\text { Daily } \\
\text { Percent }\end{array}$} & \multicolumn{3}{|c|}{$\begin{array}{c}\text { Bombay Stock Exchange } \\
\text { 1993-1995 }\end{array}$} & \multicolumn{3}{|c|}{$\begin{array}{c}\text { Bombay Stock Exchange } \\
2000-03\end{array}$} & \multicolumn{3}{|c|}{$\begin{array}{l}\text { Karachi Stock Exchange } \\
\text { 2004-06 }\end{array}$} \\
\hline & $\begin{array}{c}\text { Jan } 93 \\
\text { to } \\
\text { Dec } 95\end{array}$ & $\begin{array}{c}\text { Jan } 93 \\
\text { to } \\
\text { Feb } 94\end{array}$ & $\begin{array}{c}\text { Jun } 94 \\
\text { to } \\
\text { Dec } 95\end{array}$ & $\begin{array}{c}\text { Jan } 00 \\
\text { to } \\
\text { Mar } 03\end{array}$ & $\begin{array}{c}\text { Jan } 00 \\
\text { to } \\
\text { Jun } 01\end{array}$ & $\begin{array}{c}\text { Oct } 01 \\
\text { to } \\
\text { Mar } 03\end{array}$ & $\begin{array}{c}\text { Jan } 04 \\
\text { To } \\
\text { Aug } 06\end{array}$ & $\begin{array}{c}\text { Jan } 04 \\
\text { to } \\
\text { Feb } 05\end{array}$ & $\begin{array}{c}\text { Aug } 05 \\
\text { to } \\
\text { Aug } 06\end{array}$ \\
\hline Mean & 0.0222 & 0.1636 & -0.0503 & -0.0586 & -0.0949 & 0.0207 & 0.1170 & 0.2025 & 0.1202 \\
\hline Variance & 0.0206 & 0.0327 & 0.0126 & 0.0271 & 0.0420 & 0.0118 & 0.0248 & 0.0098 & 0.0280 \\
\hline Skewness & -0.1077 & -0.2828 & 0.1524 & -0.3388 & -0.2583 & 0.2787 & -0.4937 & -0.5222 & -0.5962 \\
\hline Kurtosis & 2.9242 & 2.1863 & 0.8294 & 2.6123 & 1.1944 & 1.2321 & 1.7263 & 2.4753 & 1.3910 \\
\hline Minimum & -0.0899 & -0.0899 & -0.0385 & -0.0742 & -0.0742 & -0.0395 & 0.1186 & -0.0356 & 0.1064 \\
\hline Maximum & 0.0563 & 0.0563 & 0.0418 & 0.0712 & 0.0712 & 0.0445 & -0.0606 & 0.0342 & -0.0606 \\
\hline Jarque-Bera & 279.77 & 64.17 & 13.449 & 256.73 & 27.52 & 29.81 & 114.53 & 91.12 & 39.58 \\
\hline Observations & 781 & 302 & 413 & 846 & 390 & 391 & 695 & 303 & 283 \\
\hline
\end{tabular}


Table-2: Test for Mean Inequality

\begin{tabular}{lcrr}
\hline \multicolumn{4}{c}{ T-Test For Mean Difference: } \\
Assuming Unequal Variances \\
\hline \multicolumn{1}{c}{ Index Return } & \multicolumn{1}{c}{ BSE30 } & BSE30 & \multicolumn{1}{c}{ KSE100 } \\
Daily Percent & $\mathbf{1 9 9 3 - 9 5}$ & $\mathbf{2 0 0 0 - 2 0 0 3}$ & $\mathbf{2 0 0 4 - 0 6}$ \\
\hline Mean Ist Sub-period & 0.1636 & -0.0949 & 0.2025 \\
Mean 2nd Sub-period & -0.0503 & 0.0207 & 0.1202 \\
t Stat & 1.8172 & -0.9848 & 0.7191 \\
$\mathrm{P}(\mathrm{T}<=\mathrm{t})$ one-tail & 0.0349 & 0.1626 & 0.2362 \\
\hline
\end{tabular}

Table-3: Test for Variance Difference

\begin{tabular}{|c|c|c|c|}
\hline \multicolumn{4}{|c|}{ Panel-A: F-Test for Unequal Variances } \\
\hline $\begin{array}{l}\text { Index Return } \\
\text { Daily Percent }\end{array}$ & $\begin{array}{c}\text { BSE30 } \\
1993-95\end{array}$ & $\begin{array}{c}\text { BSE30 } \\
2000-2003 \\
\end{array}$ & $\begin{array}{l}\text { KSE100 } \\
2004-06\end{array}$ \\
\hline Variance Ist Sub-period & 0.0327 & 0.0420 & 0.0098 \\
\hline Variance 2nd Sub-period & 0.0126 & 0.0118 & 0.0280 \\
\hline F Stat & 2.6024 & 3.5499 & 2.8469 \\
\hline $\mathrm{P}(\mathrm{F}<=\mathrm{f})$ one-tail & 0.0000 & 0.0000 & 0.0000 \\
\hline \multicolumn{4}{|c|}{$\begin{array}{l}\text { Panel-B: F-Test for Unequal Variances } \\
\text { Using Residuals from the GARCH-M Model }\end{array}$} \\
\hline $\begin{array}{l}\text { Index Return } \\
\text { Daily Percent }\end{array}$ & $\begin{array}{c}\text { BSE30 } \\
1993-95\end{array}$ & $\begin{array}{c}\text { BSE30 } \\
2000-2003\end{array}$ & $\begin{array}{l}\text { KSE100 } \\
2004-06 \\
\end{array}$ \\
\hline Variance Ist Sub-period & 0.0333 & 0.0393 & 0.0098 \\
\hline Variance 2nd Sub-period & 0.0123 & 0.0115 & 0.0280 \\
\hline F Stat & 2.6998 & 3.4099 & 2.8476 \\
\hline $\mathrm{P}(\mathrm{F}<=\mathrm{f})$ one-tail & 0.0000 & 0.0000 & 0.0000 \\
\hline
\end{tabular}


Table-4: Results of Garch Model Estimation

\begin{tabular}{lcccccc}
\hline & \multicolumn{2}{c}{ BSE30: 1993-1995 } & \multicolumn{2}{c}{ BSE30: 2000-2003 } & \multicolumn{2}{c}{ KSE100: 2004-2006 } \\
\hline Variable & Coefficient & T-Stat & Coefficient & T-Stat & Coefficient & T-Stat \\
\hline Constant $\left(\gamma_{0}\right)$ & -0.00101 & -1.16 & 0.00033 & 0.44 & 0.00227 & $4.21^{* *}$ \\
RETMSCI $\left(\gamma_{1}\right)$ & 0.20251 & $1.94^{*}$ & 0.13811 & $3.71^{* *}$ & 0.05749 & 0.83 \\
GARCH-V $\left(\gamma_{2}\right)$ & 5.72384 & 1.23 & -0.80969 & -0.23 & -0.76371 & -0.26 \\
C & 0.00003 & $2.15^{* *}$ & 0.00003 & $2.70^{* *}$ & 0.00001 & $3.43^{* *}$ \\
A & 0.10631 & $3.16^{* *}$ & 0.14492 & $4.06^{* *}$ & 0.24551 & $5.67^{* *}$ \\
B & 0.79988 & $12.43^{* *}$ & 0.75884 & $13.18^{* *}$ & 0.72977 & $19.70^{* *}$ \\
DUMMY & -0.00002 & $-2.00^{* *}$ & -0.00002 & $-2.35^{* *}$ & 0.00000 & 0.84 \\
Observations & 781 & & & 846 & & 695 \\
\hline
\end{tabular}

* and ${ }^{* *}$ indicate statistical significance level of $10 \%$ and $5 \%$ respectively.

Table-5: Autocorrelation Estimation

\begin{tabular}{|c|c|c|c|c|c|c|c|c|c|}
\hline \multirow{3}{*}{$\frac{\text { Index }}{\text { Lags }}$} & \multicolumn{3}{|c|}{ BSE30: 1993-95 } & \multicolumn{3}{|c|}{ BSE30: 2000-03 } & \multicolumn{3}{|c|}{ KSE100: 2004-06 } \\
\hline & $\begin{array}{c}\text { Jan } 93 \\
\text { to }\end{array}$ & $\begin{array}{c}\text { Jan } 93 \\
\text { to }\end{array}$ & $\begin{array}{c}\text { Jun } 94 \\
\text { To }\end{array}$ & $\begin{array}{c}\text { Jan } 00 \\
\text { to }\end{array}$ & $\begin{array}{c}\text { Jan } 00 \\
\text { to }\end{array}$ & $\begin{array}{l}\text { Oct } 01 \\
\text { to }\end{array}$ & $\begin{array}{c}\text { Jan } 04 \\
\text { to }\end{array}$ & $\begin{array}{c}\text { Jan } 04 \\
\text { to }\end{array}$ & $\begin{array}{c}\text { Aug } 05 \\
\text { to }\end{array}$ \\
\hline & Dec95 & Feb 94 & Dec 95 & Mar 03 & Jun 01 & Mar 03 & Aug 06 & Feb 05 & Aug 06 \\
\hline 1 & 0.0517 & 0.0370 & 0.0100 & 0.2263 & 0.1961 & 0.2459 & 0.0874 & -0.0366 & 0.0988 \\
\hline 2 & 0.0112 & 0.0258 & -0.0046 & -0.0017 & -0.0157 & 0.0103 & -0.0367 & 0.0366 & -0.0397 \\
\hline 3 & -0.0186 & -0.0374 & 0.0363 & -0.0101 & 0.0058 & -0.0389 & 0.0622 & 0.0718 & -0.0384 \\
\hline 4 & 0.0444 & 0.0047 & 0.1178 & 0.0010 & -0.0173 & 0.0319 & -0.0039 & 0.0247 & -0.1076 \\
\hline 5 & -0.0262 & -0.0519 & 0.0402 & -0.0398 & -0.0404 & -0.0534 & -0.0111 & 0.1112 & -0.0056 \\
\hline 6 & -0.0503 & -0.0538 & -0.0339 & -0.0198 & -0.0110 & -0.0308 & -0.0255 & 0.0831 & -0.1310 \\
\hline 7 & 0.0678 & 0.0645 & -0.0086 & -0.0073 & 0.0044 & -0.0200 & 0.0056 & 0.1071 & -0.0766 \\
\hline 8 & -0.0542 & -0.0902 & 0.0067 & -0.0108 & -0.0390 & 0.0495 & -0.0149 & -0.0184 & 0.0356 \\
\hline$Q(4-0$ & 4.3471 & 1.3595 & 6.0808 & 40.2355 & 11.9075 & 26.2478 & 8.1320 & 2.5905 & 7.0171 \\
\hline Sig. & 0.3611 & 0.8512 & 0.1932 & 0.0000 & 0.0181 & 0.0000 & 0.0869 & 0.6285 & 0.1350 \\
\hline $\mathrm{Q}(8-0)$ & 13.5393 & 8.4824 & 7.2313 & 41.9285 & 12.9303 & 29.0480 & 8.8338 & 12.2324 & 14.1139 \\
\hline Sig. & 0.0946 & 0.3878 & 0.5119 & 0.0000 & 0.1143 & 0.0003 & 0.3565 & 0.1411 & 0.0788 \\
\hline
\end{tabular}

$Q(L)$ refers to Lung Box $Q$-statistic for $L$ lags, p-values are reported below. 
Figure-1: Stock Market Indices And Volatility

A: BSE, 1993-1995 Period
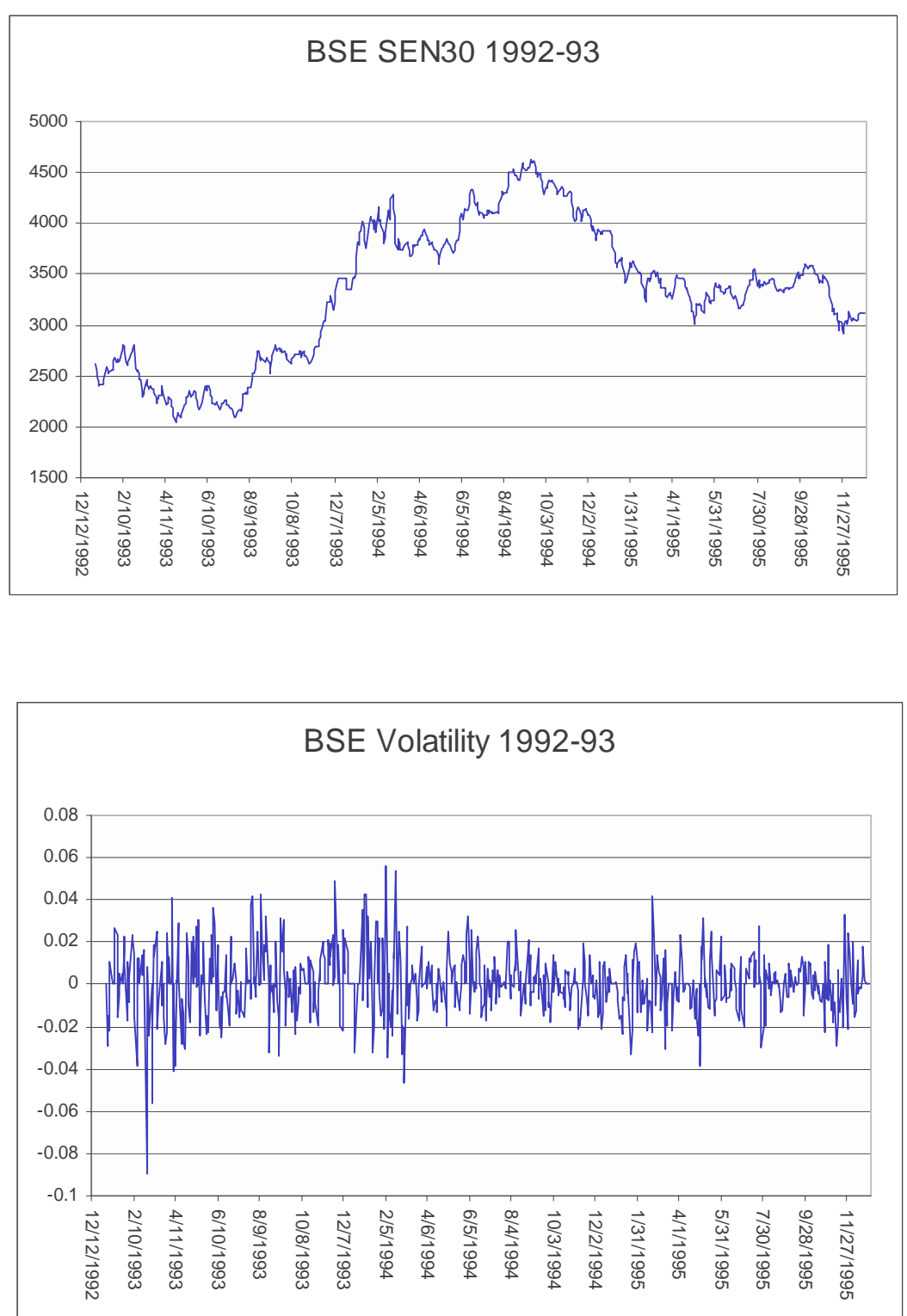


\section{B: BSE, 2000-2003 Period}
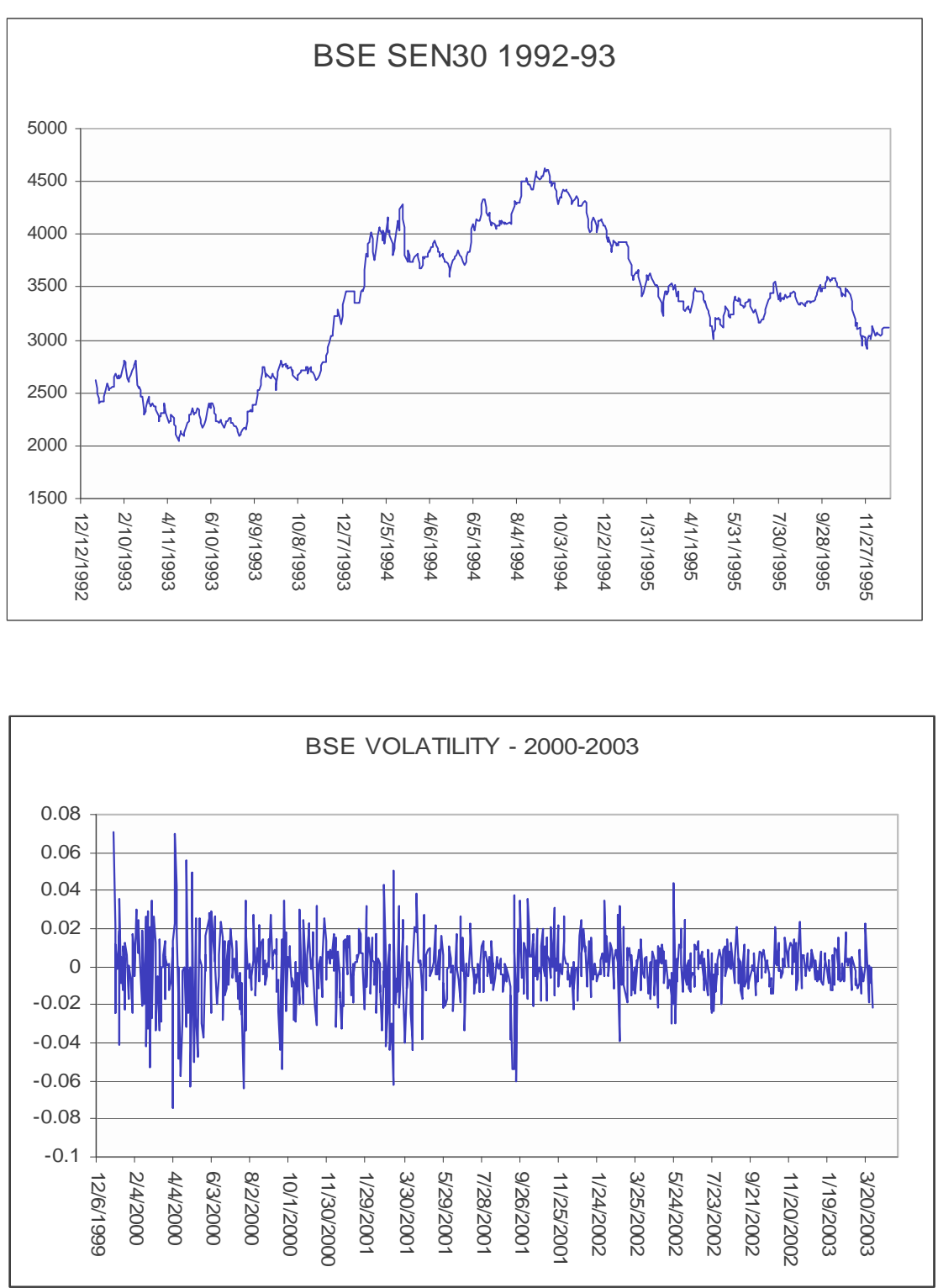


\section{C: KSE, 2004-2006 Period}
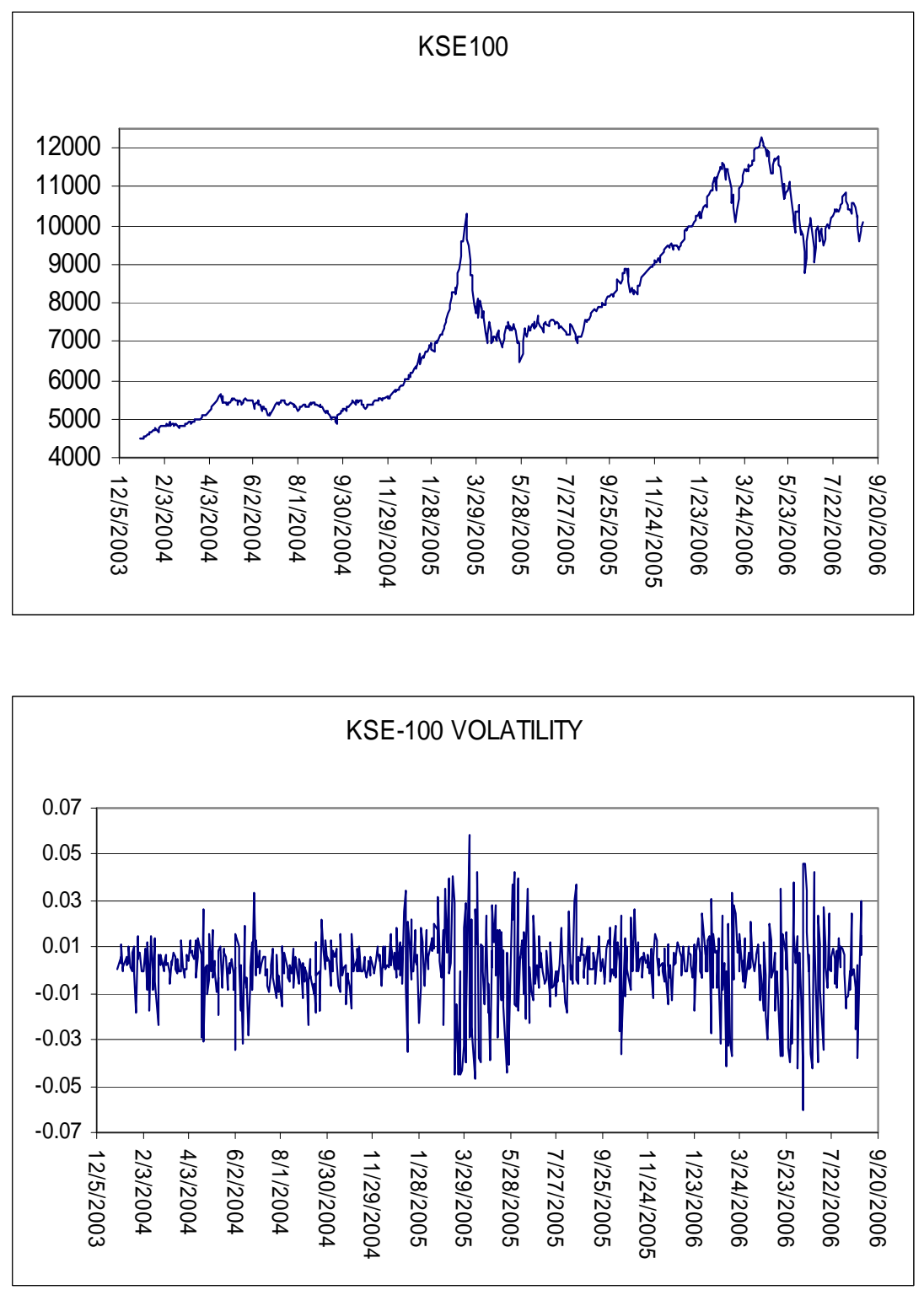


\section{References}

Ahmed, E., Rosser, J., and Uppal, J., 1996, "Asset Speculative Bubbles in emerging Markets: The Case of Pakistan," Pakistan Economic and Social Review, 34(2, Winter) pp.97-118.

Barua, S. K. and Varma, J. R., 1993, "Securities Scam: Genesis, Mechanics and Impact," Journal of the Indian Institute of Management, Ahmedabad, 18(1, January-March) 3-12.

Berkman, H., Eleswarapu, V.R., 1998, "Short-Term Traders and Liquidity: a Test Using Bombay Stock Exchange Data,” Journal of Financial Economics, 47(3, March) 339-355.

Bhattacharya, K., Sarhar, N. and Mukhopadhyay, D., 2003, "Stability of the Day of the Week Effect in Return and in Volatility at the Indian Capital Market: A GARCH Approach with Proper Mean Specification," Applied Financial Economics, 13(8, August) 553-563.

Bollerslev, T., 1986, "Generalized Autoregressive Conditional Heteroskedasticity,” Journal of Econometrics, 31(3) 307-27.

De Long, J.B., Shleifer, A., Summers, L.H. and Waldmann, R.J., 1990a, "Noise Trader Risk in Financial Markets," Journal of Political Economy. 98, 703-738.

De Long, J.B., Shleifer, A., Summers, L.H. and Waldmann, R.J., 1990b, "Positive Feedback Investment Strategies and Destabilizing Rational Speculation," Journal of Finance, 45, 379-395.

Eleswarapu, V., and Krishnamurti, C., "Do Speculative Traders Increase Stock Price Volatility? Empirical Evidence from the Bombay Stock Exchange”, Unpublished manuscript.

Engle, R. F., 1982, "Autoregressive Conditional Heteroskedasticity with Estimates of the Variance of United Kingdom Inflation," Econometrica, 50(4) 987-1007.

Engle, R. F., Lilien, D. M. and Robins, R. P., 1987, 'Estimating Time Varying Risk Premia in the Term Structure: The ARCH-M Model,' Econometrica, 55, 391-407. 
Goswami, R., and Angusham, R., 2000, "Day of the Week Effect on the Bombay Stock Exchange," ICFAI Journal of Applied Finance, 6, 3146.

Government of Pakistan: Task Force Report, July 2005.

Goyal, A., 2004, Regulation and De-regulation of the Stock Market in India, presented at the Regulation Conference of the Public Policy Program, National University of Singapore.

ICFAI, 2002, “The Ketan Parekh Scam, a Case Study," Center for Management Research, Hyderabad, (http://www.icmr.icfai.org/).

Jegadeesh, N. and Subrahmanyam, A., 1993, "Liquidity Effects of the Introduction of the S\&P 500 Index Futures Contract on the Underlying Stocks," Journal of Business, 66, 171-183.

Kane, E. J., 1983, "Policy Implications of Structural Changes in Financial Markets," The American Economic Review, 73(2, May) 96-100.

Kane, E. J., 1988, "Interaction of Financial and Regulatory Innovation," The American Economic Review, 78(2, May) 328-334.

Khanna, T., Sunder, S., 1995, “A Tale of Two Exchanges,” Harvard Business School Case Study.

Khawja, A., Mian, A., 2005, "Unchecked Intermediaries: Price Manipulation in an Emerging Stock Market,” Journal of Financial Economics, 78, 203-241.

La Porta, R., Lopez-de-Silanes, F. and Shleifer, A., 2006. What works in securities laws? The Journal of Finance, 61(1) 1-32.

Mang1a, I. and Uppa1, J., 1996, "Stability of Stock Return Distributions in Emerging Markets," Midwest Review of Finance and Insurance, 10(1, Spring) 295-306.

Nageswaran, V. A. and Krithivasan, S., 2006, "Capital Market Reforms in India and ASEAN: Avenues for Cooperation,” In Kumar, N., Sen, R. and Asher M. (Eds.), India-ASEAN Economic Relations: Meeting the Challenges of Globalization. ISEAS., Singapore.

The News, 2005, "Badla is Back," July 15, 2005. 
Shah, A. and Thomas, S., 2000, "David and Goliath: Displacing a primary market”, Journal of Global Financial Markets, 1(1) 14-21.

Shah, A. and Thomas, S., 2001, "The evolution of the securities markets in India in the 1990s," Indian Council For Research On International Economic Relations, New Delhi.

Shin, J. 2005, "Stock Returns and Volatility in Emerging Stock Markets," International Journal of Business and Economics, 4(1) 31-43.

Standard and Poor's, 2006, "Global Stock Markets Factbook-2006," McGraw-Hill, New York.

Stiglitz, J. E., 1989, "Using Tax Policy to Curb Speculative Short-Term Trading," Journal of Financial Services Research, 3, 101-15.

Wilhelm, W.J., 2001, "The Internet and Financial Market Structure”, Oxford Review of Economic Policy, 17, 2, 235-247. 